\title{
Myocardial Extramedullary Hematopoiesis: A Clinicopathologic Study
}

\author{
D. Ashley Hill, M.D., Paul E. Swanson, M.D. \\ The Lauren V. Ackerman Laboratory of Surgical Pathology, Barnes-Jewish Hospital, Washington \\ University Medical Center, St. Louis, Missouri
}

Extramedullary hematopoiesis (EMH) after fetal development is uncommon and is most often seen in patients who have hematologic disorders. EMH unassociated with hematologic disease is rare. After the recent observation of EMH in a myocardial infarct, we sought to determine the frequency and clinicopathologic setting of EMH in myocardial tissues submitted for pathologic examination. Hematoxylin and eosin (H\&E)-stained sections from 805 consecutive myocardial samples (207 surgical specimens, 598 autopsy specimens) were examined retrospectively. The presence of immature erythroid or myeloid cell clusters in intramyocardial capillaries or stroma was considered sufficient for the diagnosis of EMH. Immunoperoxidase studies confirming the nature of the hematopoietic cell infiltrate were performed in selected cases. Foci of EMH (often multiple) were identified in 15 of 207 surgical hearts (7.2\%) and in 22 of 598 autopsy hearts (3.7\%). Patient ages (exclusive of premature infants) ranged from 2 weeks to 73 years (median, 13 years). Twenty-four of 37 (65\%) EMH-positive cases were associated with infarcts in various stages of repair (accounting for 11 of 68 [16.2\%] of all infarcts in surgical specimens and 13 of 86 [15.1\%] of infarcts in autopsy specimens). Acute infarcts less than 72 hours old, excluding those with acute extension, were not associated with EMH. Viral myocarditis and myocardial hypertrophy with fibrosis accounted for primary diagnoses in the nonischemic, EMH-positive surgical cases, whereas seven of nine nonischemic, EMH-positive autopsy cases involved premature or term infants with no obvious myocardial disease. Another autopsy patient had sarcoidosis with myelophthisic involvement of her bone

Copyright (C) 2000 by The United States and Canadian Academy of Pathology, Inc.

VOL. 13, NO. 7, P. 779, 2000 Printed in the U.S.A

Date of acceptance: January 5, 2000.

Presented at the United States and Canadian Academy of Pathology Meeting, Boston, Massachusetts, March 1998.

Address reprint requests to: Paul E. Swanson, M.D., Division of Surgical Pathology, Barnes-Jewish Hospital, One Barnes-Jewish Hospital Plaza, St.

Louis, MO 63110; e-mail: swanson@path.wustl.edu; fax: 314-362-8950. marrow and represented one of only two cases overall in which a hematopoietic disorder was coexistent or suspected. Myocardial EMH is relatively common after myocardial infarct but is rarely encountered in normal or nonischemic myocardium. Its presence in healing but not early acute stages of infarct suggests that EMH results from inflammation- or repair-associated trophic factors, not from ischemia itself.

KEY WORDS: Congenital heart disease, Extramedullary hematopoiesis, Ischemic heart disease, Myocardial infarct, Myocarditis.

Mod Pathol 2000;13(7):779-787

In the developing fetus, hematopoiesis is a migratory phenomenon that arises first within the mesenchyme of the extraembryonic tissues (yolk sac, chorion, and body stalk) within 3 weeks of fertilization (1). The liver becomes the predominant site of hematopoiesis during gestational weeks 4 to 6 and remains so while the bone marrow is developing. During this period, hematopoiesis can be seen in other solid organs, including the pancreas, spleen, thymus, heart, kidneys, adrenals, gonads, skin, and lymph nodes (2). Bone marrow stroma appears first in the clavicle during the seventh and eighth developmental weeks, and active hematopoiesis follows at approximately developmental week 11 (3). Marrow hematopoiesis gradually increases and becomes the major hematopoietic organ in the middle of the third trimester (3). The significance of this time lag lies in the developing complex architecture and cellular composition of the bone marrow stroma that will provide both structural and regulatory support. By the time the fetus reaches term gestation, hepatic and other solid organ hematopoiesis has gradually diminished (4).

Extramedullary hematopoiesis (EMH) after fetal development is uncommon and is usually seen in the context of a few well-known clinical conditions. Most often it is associated with hematologic disorders, both neoplastic (e.g., myelofibrosis and the spent phase of polycythemia vera [5]) and non- 
neoplastic (as in thalassemias [6]). It has also been described in association with some tumors, including cerebellar hemangioblastomas (7), hemangiomas (8), hepatoblastomas (9), leiomyomas (10), pilomatricomas (11), hepatic angiosarcoma (12), endometrial carcinoma (13), meningioma (14), hepatic adenoma (15), mesoblastic nephroma (16), liposarcoma (17), myofibroblastic tumors and renal cell carcinomas, and in a variety of non-neoplastic environments such as allograft livers $(18,19)$, acute tubular necrosis (20), breast biopsy cavities (21), endometrial stroma (14), congenital viral infections (22), and a myocardial infarct (23). The pathophysiology of EMH in cases not associated with hematologic disorders seems to be different from EMH in myelofibrosis and the spent phase of polycythemia vera. In the former, the presence of an appropriate array of growth factors, as well as a suitable environment, usually one that is highly vascular, seems sufficient to entice circulating hematopoietic stem cells to home there. Because myocardial infarcts are frequent pathologic specimens, they represent a suitable model for studying the frequency and clinicopathologic attributes of extramedullary hematopoiesis.

\section{MATERIALS AND METHODS}

H\&E-stained sections from 805 myocardial samples were examined retrospectively (mean, $3.6 \mathrm{sec}-$ tions per case; range, 1 to 20). A total of 598 consecutive autopsy hearts representing 3 years of cases were reviewed. We reviewed 207 cases received in the surgical pathology laboratory. Endomyocardial biopsies were not included. The presence of immature erythroid or myeloid cell clusters in intramyocardial capillaries or stroma was considered sufficient for the diagnosis of EMH. Positive cases were classified according to their hematopoietic components (erythroid precursors alone, erythroid and myeloid, or trilineage), degree of hematopoiesis (single or multiple foci, number of cells/ foci), and background histology. Hearts with fewer than 50 hematopoietic cells were arbitrarily graded as $1+; 50$ to 100 cells $=2+; 101$ to 500 cells $=3+$; greater than 500 cells $=4+$. Immunohistochemical stains for myeloperoxidase (Dako, Carpinteria, CA; 1:20,000 dilution), glycophorin A (Dako; 1:400), and Factor VIII-related antigen (Dako; 1:60) were performed on 4 - $\mu$-thick sections from formalin-fixed, paraffin-embedded tissue in selected cases using an automated staining device (Autostainer, Dako). Tissue sections prepared for antibody application were immersed in citrate buffer $(0.1 \mathrm{~N}, \mathrm{pH} 6.0)$ and subjected to microwave irradiation for $8 \mathrm{~min}$. All primary antibodies were incubated with the tissue sections for $2 \mathrm{~h}$ at room temperature. Slides were then developed using a modified avidin-biotinperoxidase complex method (24) (LSAB + kits, Dako) with 3,3'-diaminobenzidine $+/ \mathrm{H}_{2} \mathrm{O}_{2}$ as chromogen/substrate. The condition of the bone marrow and presence of EMH in other sites were noted for cases in which additional pathologic material was available for review. Clinical histories including signs or symptoms of myocardial ischemia, hematologic disorders, and medications were retrospectively reviewed when available.

\section{RESULTS}

\section{Clinicopathologic Characteristics of the Study Group}

Some inherent differences were noted in the clinical characteristics of the groups studied (autopsy patients versus surgical patients). In the group of 598 autopsy cases, patients' ages ranged from 20 weeks' gestation to 101 years (mean age, 42.5 years). As expected, there was a wide range of diagnoses. Cardiac disease including congenital anomalies, valvular disease, hypertrophy, myocarditis, and coronary artery disease were noted in 263 patients (44\%). In the group of 207 surgical cases, patients' ages ranged from 1 day to 69 years (mean age, 26.3 years). A total of 190 (92\%) of the surgical cases were heart explants with a wide spectrum of pathologic abnormalities, including congenital heart disease, cardiomyopathies, and ischemic heart disease. The remainder of surgical cases were obtained from aneurysm resections $(n=4)$, septal defect repairs $(n=3)$, or revisions of prior congenital heart disease operations $(n=10)$. Eighty-six of the autopsy cases (14\%) and 68 of the surgical cases (33\%) showed morphologic evidence of infarcts of varying ages. Of the 68 surgical cases showing myocardial infarcts, 14 patients were younger than 21 years.

Myocardial EMH was seen in 37 patients (15 surgical cases and 22 autopsy cases) with ages ranging from 20 weeks' gestation to 73 years. Excluding premature infants, the mean age was 19.9 years (median, 13 years). The incidence of myocardial EMH was much higher in stillborn infants and children younger than 1 year (Fig. 1). Beyond 1 year, there was no correlation between age and frequency of EMH. Clinical diagnoses, complete blood counts, cause of death, and other hematologic and pathologic data from the EMH-positive surgical and autopsy patients are summarized in Tables 1 and 2, respectively. Fourteen of 15 surgical patients with myocardial EMH underwent cardiac transplantation for a variety of underlying conditions, including ischemic heart disease (4 patients), dilated cardiomyopathy (3 patients), congenital heart disease (6 patients), and viral myocarditis (1 patient). One 


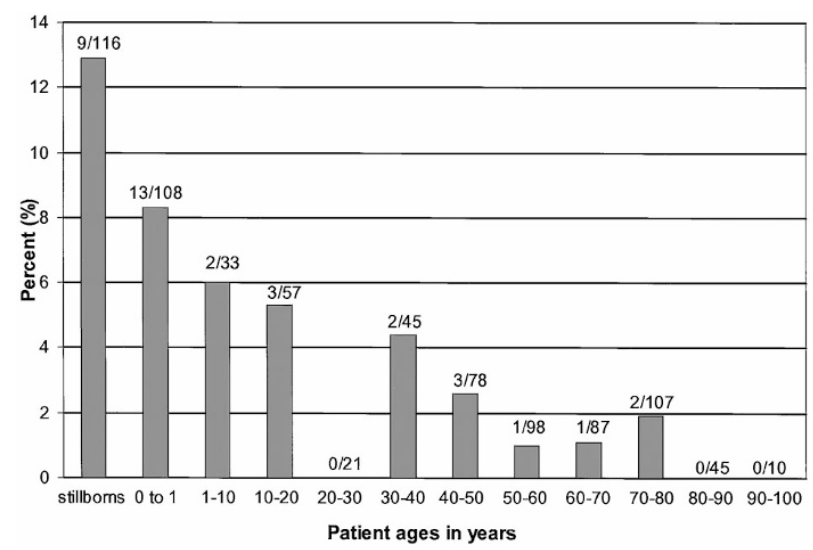

FIGURE 1. Comparison of age and extramedullary hematopoiesis (EMH) incidence. The incidence of myocardial EMH was higher in stillborn infants and children younger than 1 year. Beyond 1 year, the incidence of EMH gradually decreased with age.

patient (Patient 7) had an aneurysm resection; the aneurysm was the result of a previous myocardial infarction. Thirteen of the 15 patients showed hemodynamic instability in the days before their procedures, and 10 had known or suspected recent myocardial infarcts by history and/or cardiac enzyme analysis. Another patient had a clinically documented infarct 4 months before aneurysm resection. None of the patients was being treated with colony-stimulating factors or erythropoietin at the time of operation; however, several of the transplant patients were started on immunosuppressive agents (notably, azathioprine and glucocorticoids) just before operation. Patients 2 and 8 had at least one abnormal hematologic parameter. Pancytopenia found in Patient 2 was attributed to hypersplenism secondary to hepatitis $\mathrm{C}$ cirrhosis and portal hypertension. Patient 8 has been previously described by Marley et al. (23) and involved a 13year-old patient with aortic stenosis who had EMH in his explanted, infarcted heart. At the time of operation, he had mild thrombocytopenia, although a global hematologic disorder was not suspected. Bone marrow examination during a subsequent autopsy showed dysplastic erythroid elements and limited maturation of myeloid elements with increased early forms. EMH was not detected in the donor heart or other organs (save for a few nucleated red blood cells in the spleen), and there was no evidence of cardiac ischemic injury in the donor heart.

Excluding the eight premature fetuses and one 42-week-gestation neonate, the cause of death in EMH-positive autopsy patients was related to cardiac ischemia in 9 of 13 cases. All were hemodynamically unstable during the last few days of life; seven patients were in cardiogenic shock, and three were in septic shock. None of the patients had a clinically suspected hematologic disorder before death, and none was taking colony-stimulating fac- tors or erythropoietin. At autopsy, bone marrow examination of a 36-year-old patient with sarcoidosis showed granulomas (Patient 18) but was unremarkable in all other cases. EMH was found in other organs in most of the stillborn infants and three other autopsy patients (aged 2 weeks to 4 months). The most common site of extracardiac $\mathrm{EMH}$ was the liver (nine patients) followed by spleen (three patients), thymus, adrenal, testis, and kidney (one patient each).

\section{Pathologic Data}

Foci of EMH were identified in 15 of 207 surgical samples (7.2\%) and 22 of 598 autopsy hearts (3.7\%). The extent was highly variable from case to case, ranging from a single focus of 10 to 15 cells in one tissue section to multiple foci of hundreds of cells in multiple tissue sections (Table 3 ). The components of EMH were also variable. Erythroid and myeloid precursors were seen alone in 12 and 2 cases, respectively, together in 17 cases, and together with megakaryocytes in 6 cases. The late erythroid precursors were easily recognizable by their jet-black, round nuclei and moderate amount of pale pink cytoplasm. These tended to cluster in areas of granulation tissue (Fig. 2). At low power, the myeloid cells resembled large lymphocytes but with careful examination could be distinguished by their characteristic cytologic features-large nuclei with immature, dispersed chromatin, nucleoli, and a high nuclear:cytoplasmic ratio. Myeloid elements were most readily identifiable when clustered in association with immature erythroid elements, which occurred in the majority of the cases (Figs. 2 and 3). These tended to form relatively cohesive groups, although occasionally they appeared more infiltrative (Fig. 4). Vessels that were expanded with marginating erythroid precursors simulated the pattern of an intravascular lymphoma or leukemia (Fig. 5). Definitive megakaryocytes were noted in only six cases and were identified by both their size and morphologic features. Although the criteria for inclusion as an EMH-positive case was recognition with $H \& E$ staining, immunohistochemical stains for glycophorin A (Fig. 6), myeloperoxidase (Fig. 7). and Factor VIII-related antigen were performed on selected cases (Patients 5, 8, 13, 15, 28, 33), confirming the identity of the hematopoietic cells, erythroid, myeloid, and megakaryocytic, respectively.

Eleven of 15 EMH-positive surgical cases (73\%) and 13 of $22 \mathrm{EMH}$ positive autopsy cases (59\%) were associated with acute myocardial infarcts in varying stages of repair (accounting for 11 of 68 [16.2\%] of all infarcts in surgical specimens and 13 of 86 [15.1\%] of all infarcts in autopsy specimens). With the use of a combination of morphologic characteristics (Table 4) and clinical information (when 
TABLE 1. Summary of Clinical Data for Surgical Patients with Myocardial EMH

\begin{tabular}{|c|c|c|c|c|c|c|c|}
\hline Patient & Age & Sex & Clinical Diagnosis & WBC & Hgb & Plt & Other Clinical Information \\
\hline 1 & $72 \mathrm{y}$ & $\mathrm{F}$ & Ischemic heart disease & 16.3 & 10.2 & 180 & \\
\hline 2 & $50 \mathrm{y}$ & M & Ischemic heart disease & 2.8 & 11.9 & 92 & $\begin{array}{l}\text { Hypersplenism secondary to portal } \\
\text { hypertension/cirrhosis }\end{array}$ \\
\hline 3 & $48 \mathrm{y}$ & $\mathrm{F}$ & Ischemic heart disease & 5.4 & 13.1 & 270 & \\
\hline 4 & $47 \mathrm{y}$ & $\mathrm{F}$ & Myocardial infarct & 14.7 & 12.9 & 390 & \\
\hline 5 & $44 \mathrm{y}$ & M & Ischemic heart disease & 7.2 & 15.2 & 231 & \\
\hline 6 & $19 \mathrm{y}$ & M & L-Transposition & 9.7 & 13.2 & 360 & \\
\hline 7 & $14 \mathrm{y}$ & $\mathrm{F}$ & Dilated cardiomyopathy & 9.9 & 12.1 & 450 & \\
\hline $8^{23}$ & $13 \mathrm{y}$ & M & Aortic stenosis & 10.9 & 11.5 & 93 & $\begin{array}{l}\text { Early myelodysplasia by marrow } \\
\text { examination at autopsy }\end{array}$ \\
\hline 9 & $13 \mathrm{y}$ & $\mathrm{F}$ & Dilated cardiomyopathy & 9.0 & 13.7 & 274 & \\
\hline 10 & $9 \mathrm{y}$ & M & Dilated cardiomyopathy & 4.6 & 13.1 & 179 & \\
\hline 11 & $5 \mathrm{y}$ & $\mathrm{M}$ & Hypoplastic left ventricle & 9.1 & 12.2 & 290 & \\
\hline 12 & $3 \mathrm{mo}$ & $\mathrm{F}$ & Hypoplastic left ventricle & 10.4 & 12.5 & 415 & \\
\hline 13 & $1 \mathrm{mo}$ & $\mathrm{F}$ & Hypoplastic left ventricle & & & & No clinical data available \\
\hline 14 & $1 \mathrm{mo}$ & M & Viral myocarditis & 13.4 & $39 \%$ & 120 & Coxsackie B2 encephalitis \\
\hline 15 & $1 \mathrm{mo}$ & $\mathrm{M}$ & $\begin{array}{l}\text { Mitral stenosis/anomalous } \\
\text { pulmonary venous } \\
\text { return }\end{array}$ & 8.2 & 12.3 & 355 & \\
\hline
\end{tabular}

EMH, extramedullary hematopoiesis; WBC, white blood count ( $\times 1000 /$ cumm); Hgb, hemoglobin in g/dL (Patient 14 shows hematocrit only); Plt, platelet count $(\times 1000 /$ cumm $)$.

TABLE 2. Summary of Clinical Data for Autopsy Patients with Myocardial EMH

\begin{tabular}{|c|c|c|c|c|c|}
\hline Patient & Age & Sex & Clinical Diagnosis & Cause of Death & Other Autopsy Findings \\
\hline 16 & $73 \mathrm{y}$ & $\mathrm{M}$ & Myocardial infarct & Myocardial infarct & \\
\hline 17 & $62 \mathrm{y}$ & $\mathrm{F}$ & Ischemic heart disease & Probable arrhythmia & \\
\hline 18 & $36 \mathrm{y}$ & $\mathrm{F}$ & Sarcoidosis & Diffuse alveolar damage & Sarcoidosis in marrow \\
\hline 19 & $35 \mathrm{y}$ & $\mathrm{F}$ & Aortic stenosis & Myocardial infarct/sepsis & \\
\hline 20 & $14 \mathrm{y}$ & M & Dilated cardiomyopathy & $\begin{array}{l}\text { Myocardial infarct/intracranial } \\
\text { hemorrhage }\end{array}$ & \\
\hline 21 & $1 \mathrm{y}$ & $\mathrm{F}$ & $\begin{array}{l}\text { Complex congenital heart } \\
\text { disease }\end{array}$ & Myocardial infarct & \\
\hline 22 & $7 \mathrm{mo}$ & M & Tetralogy of Fallot & Cardiogenic shock & \\
\hline 23 & $4 \mathrm{mo}$ & $\mathrm{F}$ & Lung transplant/ECMO & Infarcts of left lung and heart & Kidney EMH \\
\hline 24 & $4 \mathrm{mo}$ & $\mathrm{M}$ & Tetralogy of Fallot/ECMO & $\begin{array}{l}\text { Myocardial infarct/diffuse } \\
\text { alveolar damage }\end{array}$ & \\
\hline 25 & $4 \mathrm{mo}$ & M & CHARGE/ECMO & Cardiogenic shock & \\
\hline 26 & $3 \mathrm{mo}$ & $\mathrm{F}$ & $\begin{array}{l}\text { S/P heart transplant for } \\
\text { congenital heart } \\
\text { disease }\end{array}$ & Bronchopneumonia/sepsis & Spleen EMH \\
\hline 27 & $2 \mathrm{wk}$ & $\mathrm{F}$ & Truncus arteriosis & Fungal pneumonia/sepsis & Liver/Thymus/Adrenal EMH \\
\hline 28 & $2 \mathrm{wk}$ & $\mathrm{M}$ & Tetralogy of Fallot & Cardiogenic shock/DIC & \\
\hline 29 & 42 wk gestation & M & Meconium aspiration & Meconium aspiration & Liver/Spleen/Testes EMH \\
\hline 30 & 33 wk gestation & $\mathrm{F}$ & Metatropic dysplasia & Immaturity & \\
\hline 31 & SB 30 wk & M & Intrauterine fetal death & Placental abruption & Spleen/Liver EMH \\
\hline 32 & SB 24 wk & M & Intrauterine fetal death & Immaturity & Liver EMH \\
\hline 33 & SB 23 wk & $\mathrm{F}$ & $\begin{array}{l}\text { Premature rupture of } \\
\text { membranes }\end{array}$ & Immaturity & Liver EMH \\
\hline 34 & SB $21 \mathrm{wk}$ & $\mathrm{F}$ & Trisomy 16 & Immaturity & Liver EMH \\
\hline 35 & SB 21 wk & $\mathrm{F}$ & $\begin{array}{l}\text { Premature rupture of } \\
\text { membranes }\end{array}$ & Immaturity & Liver/Pancreas EMH \\
\hline 36 & SB 20 wk & M & Cystic renal dysplasia & Elective induction & Liver EMH \\
\hline 37 & SB 20 wk & $\mathrm{F}$ & Conjoined twins & Elective induction & Liver EMH \\
\hline
\end{tabular}

EMH, extramedullary hematopoiesis; SB, stillbirth; ECMO, extracorporeal membrane oxygenation; CHARGE, association that includes coloboma, heart disease, atresia choanae, and retarded growth and development; DIC, disseminated intravascular coagulation.

available), an attempt was made to date the ischemic injury for each EMH-positive case associated with an infarct. In most cases, the background myocardium showed myocyte damage with a mixture of lymphocytes, macrophages, and fibroblasts in a loose, vascular stroma consistent with infarcts in the early healing stage (days 7 to 14). Early infarcts composed solely of neutrophils and damaged myocardial fibers were not associated with EMH. Extension of EMH into the pericardium was seen in six cases associated with myocardial infarcts (three autopsy and three surgical). Based solely on data from surgical patients, myocardial infarcts in patients who were younger than 21 years were more likely to show EMH than those of their adult counterparts: 6 of $14(43 \%)$ compared with 5 of 54 (9\%). Extent of EMH seemed to correlate with infarct age but not patient age (Figs. 8 and 9, respectively).

Of the 13 instances of EMH that were not associated with infarcts, there were 1 term and 7 pre- 


\begin{tabular}{|c|c|c|c|c|c|c|c|}
\hline Patient & Age & Clinical Diagnosis & Background Histology & $\begin{array}{l}\text { Estimated } \\
\text { Infarct Age }\end{array}$ & $\begin{array}{l}\text { Cell } \\
\text { Types }\end{array}$ & Foci & Amount \\
\hline 1 & $72 \mathrm{y}$ & Ischemic heart disease & Infarcts & $2-8 w k$ & $\mathrm{E}$ & S & $1+$ \\
\hline 2 & $50 \mathrm{y}$ & Ischemic heart disease & Infarcts & $10-14 \mathrm{~d}$ & E,M & S & $1+$ \\
\hline 3 & $48 \mathrm{y}$ & Ischemic heart disease & Infarcts & $7-10 \mathrm{~d}$ & E,M & M & $2+$ \\
\hline 4 & $47 \mathrm{y}$ & Myocardial infarct & Infarcts & $7-10 \mathrm{~d}$ & E,M & M & $2+$ \\
\hline 5 & $44 \mathrm{y}$ & Ischemic heart disease & Infarcts & $10-14 \mathrm{~d}$ & $\mathrm{E}, \mathrm{M}$ & M & $3+$ \\
\hline 6 & $19 \mathrm{y}$ & L-Transposition & Hypertrophy/fibrosis & NA & E & S & $1+$ \\
\hline 7 & $14 \mathrm{y}$ & Dilated cardiomyopathy & Infarcts & $7-10 \mathrm{~d}$ & $\mathrm{E}, \mathrm{M}, \mathrm{Me}$ & M & $2+$ \\
\hline $8^{23}$ & $13 \mathrm{y}$ & Aortic stenosis & Infarcts & $10-14 \mathrm{~d}$ & $\mathrm{E}, \mathrm{M}, \mathrm{Me}$ & M & $4+$ \\
\hline 9 & $13 \mathrm{y}$ & Dilated cardiomyopathy & Infarcts & $3-7 \mathrm{~d}$ & $\mathrm{E}$ & S & $1+$ \\
\hline 10 & $9 \mathrm{y}$ & Dilated cardiomyopathy & Hypertrophy/fibrosis & NA & $\mathrm{E}$ & S & $1+$ \\
\hline 11 & $5 \mathrm{y}$ & Hypoplastic left ventricle & Hypertrophy & NA & E & M & $2+$ \\
\hline 12 & $3 \mathrm{mo}$ & Hypoplastic left ventricle & Infarcts & $3-7 \mathrm{~d}$ & E,M & M & $2+$ \\
\hline 13 & $1 \mathrm{mo}$ & Hypoplastic left ventricle & Infarcts & $7-10 \mathrm{~d}$ & $\mathrm{E}, \mathrm{M}$ & M & $4+$ \\
\hline 14 & $1 \mathrm{mo}$ & Viral myocarditis & Myocarditis & NA & $\mathrm{E}, \mathrm{M}$ & M & $3+$ \\
\hline 15 & $1 \mathrm{mo}$ & $\begin{array}{l}\text { Mitral stenosis/anomalous } \\
\text { venous return }\end{array}$ & Infarcts & $\begin{array}{l}\text { 10-14 d with } 3-7 \\
\text { d component }\end{array}$ & E,M,Me & M & $3+$ \\
\hline 16 & $73 \mathrm{y}$ & Myocardial infarct & Infarcts & $2-8 \mathrm{wk}$ & $\mathrm{E}$ & S & $1+$ \\
\hline 17 & $62 \mathrm{y}$ & Ischemic heart disease & Infarcts & $2-8 \mathrm{wk}$ & E,M & M & $2+$ \\
\hline 18 & $36 \mathrm{y}$ & Sarcoidosis & NHPA & NA & E & S & $2+$ \\
\hline 19 & $35 \mathrm{y}$ & Aortic stenosis & Infarcts & $10-14 \mathrm{~d}$ & E,M & M & $2+$ \\
\hline 20 & $14 \mathrm{y}$ & Dilated cardiomyopathy & Infarcts & $10-14 \mathrm{~d}$ & $\mathrm{E}, \mathrm{M}$ & S & $1+$ \\
\hline 21 & $1 \mathrm{y}$ & Complex congenital heart disease & Calcification/necrosis & $3-7 \mathrm{~d}$ & $\mathrm{E}, \mathrm{M}$ & M & $2+$ \\
\hline 22 & $7 \mathrm{mo}$ & Tetralogy of Fallot & Infarcts & $3-7 \mathrm{~d}$ & M & S & $1+$ \\
\hline 23 & $4 \mathrm{mo}$ & Lung transplant/ECMO & Infarcts & $7-10 \mathrm{~d}$ & $\mathrm{E}, \mathrm{M}$ & M & $4+$ \\
\hline 24 & 4 mo & Tetralogy of Fallot/ECMO & Infarcts & $7-10 \mathrm{~d}$ & $\mathrm{E}, \mathrm{M}, \mathrm{Me}$ & M & $3+$ \\
\hline 25 & 4 mo & CHARGE syndrome/ECMO & Infarcts & $7-10 \mathrm{~d}$ & $\mathrm{E}, \mathrm{M}$ & S & $2+$ \\
\hline 26 & $3 \mathrm{mo}$ & $\begin{array}{l}\text { Status post heart transplant for } \\
\text { congenital heart disease }\end{array}$ & Hemorrhagic infarct & $3-7 \mathrm{~d}$ & $\mathrm{E}, \mathrm{M}$ & $\mathrm{S}$ & $1+$ \\
\hline 27 & $2 \mathrm{wk}$ & Truncus arteriosis & Hemorrhagic infarct & $3-7 \mathrm{~d}$ & E,M & M & $3+$ \\
\hline 28 & $2 \mathrm{wk}$ & Tetralogy of Fallot & Infarcts & $7-10 \mathrm{~d}$ & $\mathrm{E}, \mathrm{M}, \mathrm{Me}$ & M & $3+$ \\
\hline 29 & $42 \mathrm{wk}$ gestation & Meconium aspiration & NHPA & NA & $\mathrm{E}$ & S & $1+$ \\
\hline 30 & 33 wk gestation & Metatropic dysplasia & NHPA & NA & $\mathrm{E}, \mathrm{M}, \mathrm{Me}$ & S & $1+$ \\
\hline 31 & SB $30 \mathrm{wk}$ & Intrauterine fetal death & NHPA & NA & M & S & $1+$ \\
\hline 32 & SB $24 \mathrm{wk}$ & Intrauterine fetal death & Necrosis & $\begin{array}{l}\text { Necrosis without } \\
\text { inflammation }\end{array}$ & $\mathrm{E}$ & S & $2+$ \\
\hline 33 & SB 23 wk & Prematurity & NHPA & NA & $\mathrm{E}$ & S & $1+$ \\
\hline 34 & SB $21 \mathrm{wk}$ & Trisomy 16 & NHPA & NA & $\mathrm{E}$ & S & $1+$ \\
\hline 35 & SB $21 \mathrm{wk}$ & Prematurity & NHPA & NA & E & S & $1+$ \\
\hline 36 & SB $20 \mathrm{wk}$ & Cystic renal dysplasia & NHPA & NA & E,M & M & $2+$ \\
\hline 37 & SB $20 \mathrm{wk}$ & Conjoined twins & NHPA & NA & E,M & S & $1+$ \\
\hline
\end{tabular}

EMH, extramedullary hematopoiesis; SB, stillbirth; ECMO, extracorporeal membrane oxygenation; CHARGE, association that includes coloboma, heart disease, atresia choanae, and retarded growth and development; NHPA, no histopathologic abnormality; E, erythroid; M, myeloid; Me, megakaryocytic; S, single; M, multiple; $1+,<50$ cells; $2+, 50-100$ cells; $3+, 101-500$ cells; $4+,>500$ cells.

mature infants with no evidence of myocardial disease, 1 patient with active viral myocarditis (presumed Coxsackie B2 diagnosed by cerebrospinal fluid culture in an infant with concurrent encephalitis), 3 patients with myocyte hypertrophy and fibrosis, and 1 with sarcoidosis involving the bone marrow.

\section{DISCUSSION}

Extramedullary hematopoiesis, the presence of blood-forming cells outside their normal marrow compartment, has been described in a variety of locations and has been associated with a variety of disorders. Recognizing the clinicopathologic setting in which EMH occurs is important, because the pathogenetic mechanisms and resulting biologic behavior of this phenomenon are diverse. Over the past several years, there have been a variety of theories to explain the presence of $\mathrm{EMH}$ in the setting of myeloproliferative disorders, including the "neoplastic theory" (25), the "compensatory theory" (26), and the "myelostimulatory theory" (27). An alternative hypothesis has been put forward by Wolf and Neiman (28), who suggested that $\mathrm{EMH}$ in the setting of myelofibrosis, the spent phase of polycythemia vera, and carcinoma metastatic to bone marrow (29) seems to be the result of abnormal release of hematopoietic precursors into the blood as a result of alterations in marrow architecture. Although the spleen is the organ most adept at filtering these cells from the bloodstream (leading to splenomegaly), the occurrence and resulting complications of EMH in other sites are well documented. EMH outside the setting of hematologic disorders is less common and probably less clinically important. Most reports involving patients without hematologic disorders describe the presence of EMH as an incidental finding. Its major clinical significance is in its recognition as an epi- 


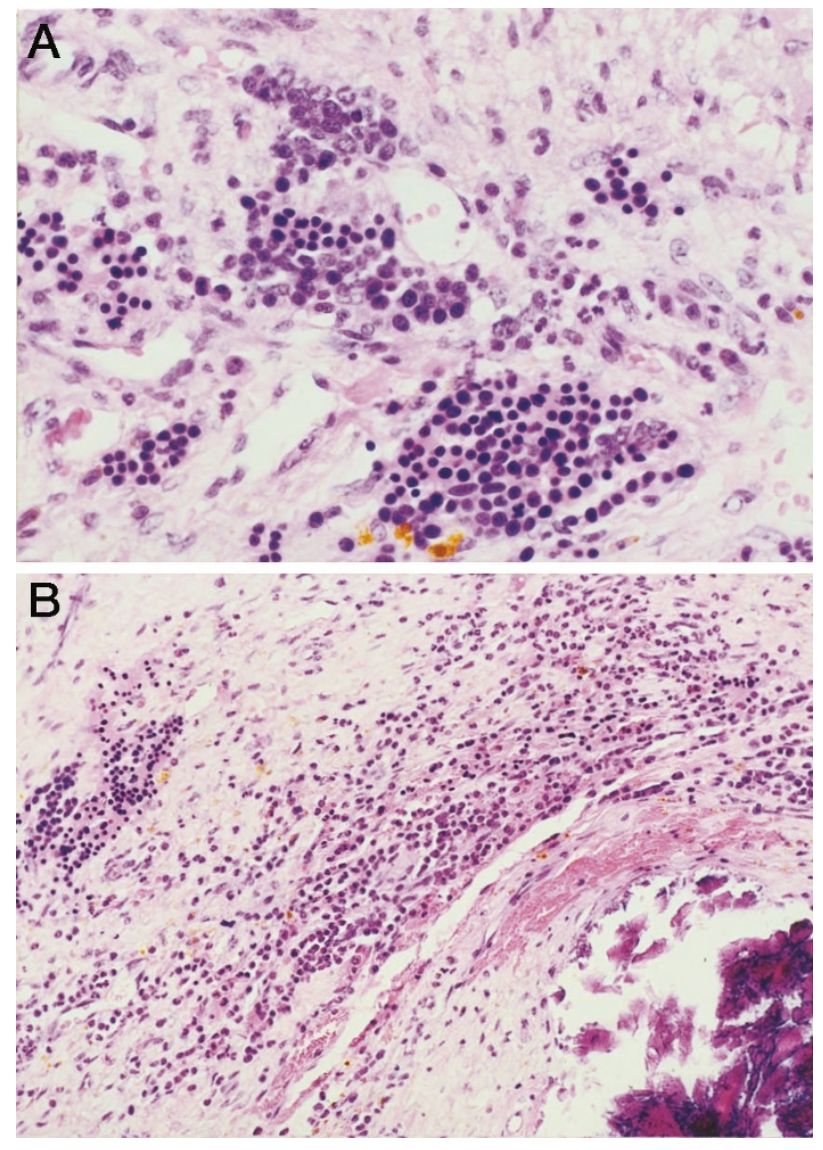

FIGURE 2. A, erythroid precursors clustered in an area of granulation tissue. Scattered groups of myeloid precursors interspersed (Patient 14). B, clusters of erythroid and myeloid precursors in a healing infarct from an infant. Note the calcification and granulation tissue in the background. The acute inflammation suggests recurrent ischemia (acute extension; Patient 15; hematoxylin and eosin, $\times 100$, $\times 50)$.

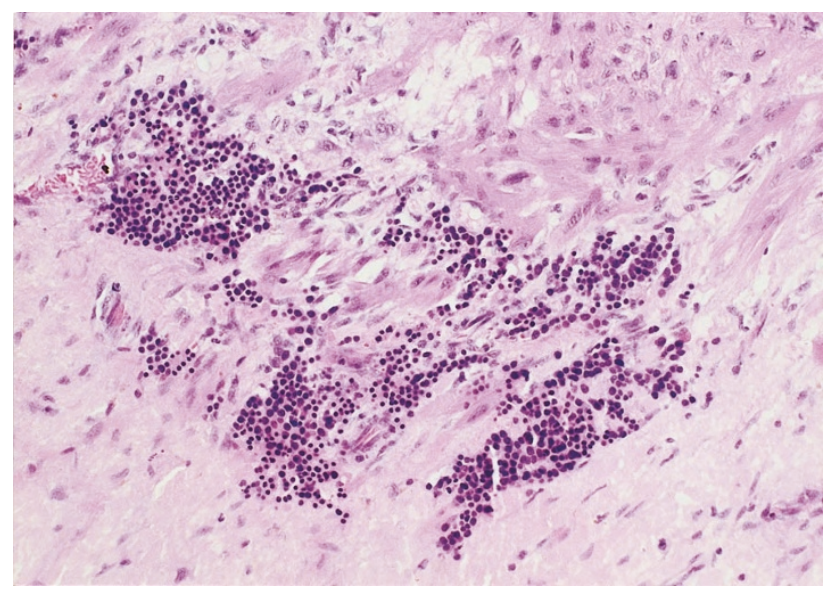

FIGURE 3. Erythroid and myeloid precursors at the periphery of a healed infarct (Patient 13; hematoxylin and eosin, $\times 50$ ).

phenomenon, rather than the leukemia, lymphoma, or other infiltrative neoplasms (e.g., lobular carcinoma of the breast) that it may resemble in exceptional cases. Despite a probable lack of biologic consequence, EMH in this clinicopathologic

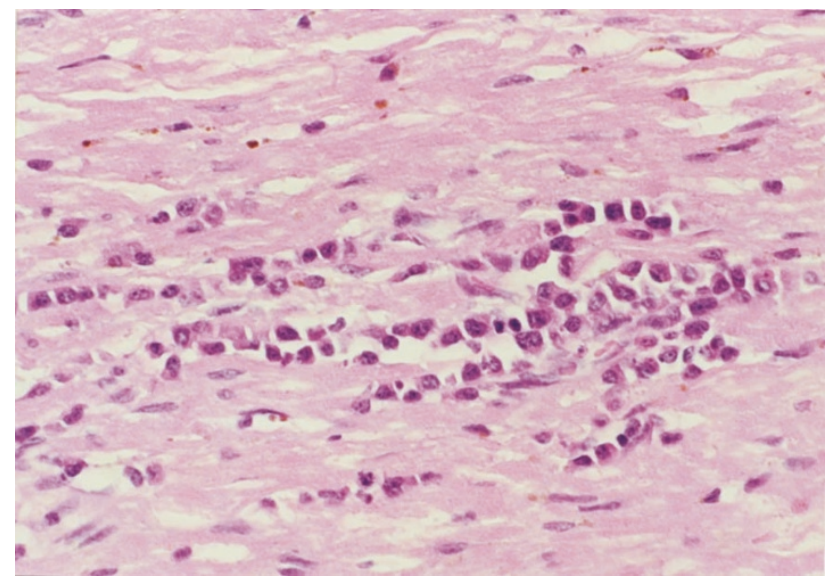

FIGURE 4. Infiltrating erythroid precursors mimicking lobular carcinoma of the breast. These cells were glycophorin A positive (Patient 13; hematoxylin and eosin, $\times 50$ ).
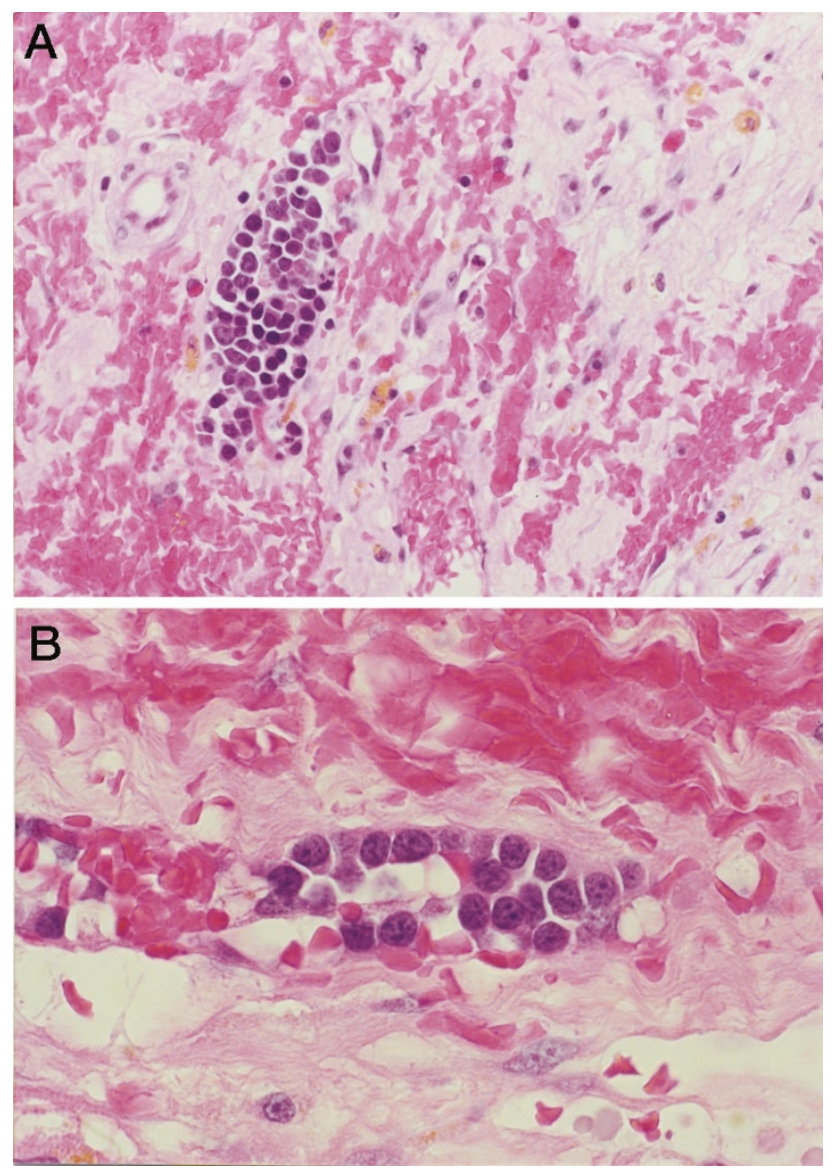

FIGURE 5. Marginating erythroid and myeloid precursors in intramyocardial vessels (Patient 5; hematoxylin and eosin). A, $\times 132$; B, $\times 150$.

setting nonetheless offers the interested observer a glimpse at the relationship between tissue injury and $\mathrm{EMH}$, and its study may form the basis of future investigation. In our report, the frequency of $\mathrm{EMH}$ in myocardial specimens (approximately 4 cases per 100 examined) was higher than expected. Also surprising is that myocardial EMH was not 


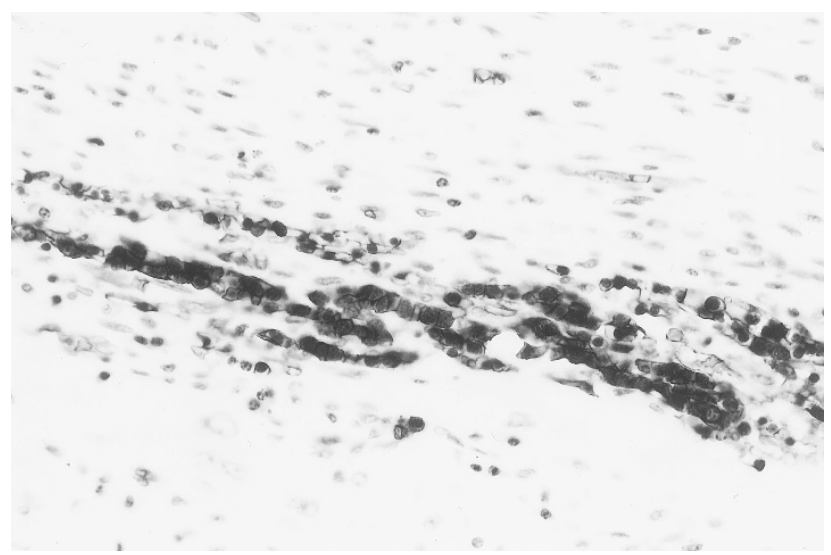

FIGURE 6. Immunohistochemical stain for glycophorin A stains these erythroid precursors as well as the surrounding mature red blood cells (Patient 8; antiglycophorin A antibody, $\times 50$ ).

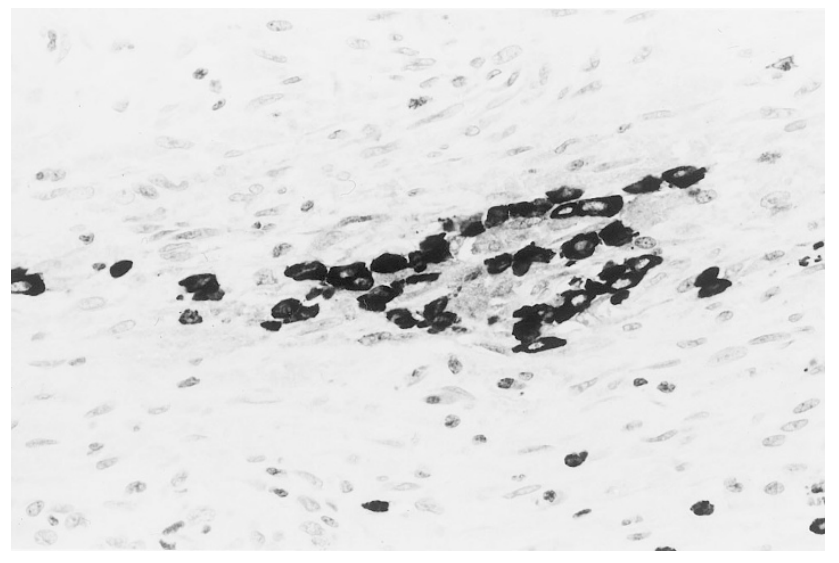

FIGURE 7. Immunohistochemical stain for myeloperoxidase identifies these mononuclear cells as immature myeloid elements (Patient 5; antimyeloperoxidase antibody, $\times 50$ ).

limited to the pediatric age group. Excluding term and premature infants, when EMH could still be considered physiologic, the patients showed a wide age range; the oldest patient was 73 years of age. The patients had in common risk factors for cardiac ischemia, including coronary artery disease, cardiomyopathies, and congenital heart disease. Although not commonly thought of as being at especially high risk for cardiac ischemia, our patients with congenital heart disease were often put at risk during complicated surgical corrective procedures, most of which required extracorporeal membrane oxygenation. Most patients had unstable hemodynamic parameters in the few days before operation or death. The vast majority had no evidence of an underlying hematologic disorder; specifically, none had evidence of myelofibrosis, polycythemia vera, or thalassemia, and none was taking colonystimulating factors or erythropoietin near the time of operation or death.

Another shared feature was the close association of EMH with the healing phase of myocardial infarcts. Although the amount of EMH varied from case to case, it was most prominent in hearts with abundant granulation tissue and large numbers of fibroblasts, macrophages, and lymphocytes. EMH was seen in stroma and within vessels. In the more florid cases, immature erythroid and/or myeloid elements simulated leukemia, intravascular lymphoma, or infiltrating lobular carcinoma of the breast. The presence of EMH in healing but not in acute stages of infarct suggests that EMH results from inflammation- or repair-associated trophic factors, not from ischemia itself. This suggests that the healing infarct provides both the architecture (loose connective tissue with neovascularization) and the cellular components that provide the necessary growth factors for circulating hematopoietic cells to home and grow. It seems that tissue EMH arises from circulating peripheral blood stem cells that are attracted to an area of injury, presumably through the local effect of chemical mediators. This would explain the presence of intravascular, marginating immature myeloid and erythroid elements seen in some of our cases. The presence of EMH in breast biopsy cavities also offers support for this view (21).

Although the chemical mediators responsible for this migration are not specifically known, the cellular components of the healing infarct are recognized sources of hematopoietic growth factors such as interleukin-3 (activated T-lymphocytes) and granulocyte macrophage-colony stimulating factor (activated macrophages, T-lymphocytes, endothelial cells, and fibroblasts) $(30,31)$. The potential contribution of myocardial ischemia, infection, and shock to systemic release of these cytokines and/or stem cells is unknown.

The conclusions we have reached are similar to those of Schlitt et al. (19) in their aspiration cytologic study of EMH in human liver grafts. They proposed that the local microenvironment of the transplant liver is most important in facilitating the production of EMH. EMH was maximal at the end of the first postoperative week. In addition (although not statistically significant), the patients who experienced more severe preservation damage subsequently developed intrahepatic erythropoiesis. Although this group made no definitive conclusions on the source of these hematopoietic stem cells (originating within the graft or from a circulating population), in the cases that were informative, the cells were of the recipient type.

The results of our study, in addition to documenting the clinicopathologic setting in which myocardial EMH may occur, provide us with an unexpected portal on the local effects of tissue injury and repair. If EMH in nonhematologic disorders are ultimately linked to locally produced trophic or colony-stimulating factors as we propose, then the surprise of this observation is not that 


\begin{tabular}{cl}
\hline Time & Microscopic Features \\
\hline $4-12 \mathrm{~h}$ & Early changes of coagulation necrosis and hemorrhage \\
$12-24 \mathrm{~h}$ & Continued coagulation necrosis, early neutrophilic infiltrate \\
$1-3 \mathrm{~d}$ & Coagulation necrosis, interstitial neutrophilic infiltrate \\
$3-7 \mathrm{~d}$ & Dying neutrophils, early phagocytosis of dead cells by macrophages \\
$7-10 \mathrm{~d}$ & Well-developed phagocytosis, early formation of fibrovascular granulation tissue \\
$10-14 \mathrm{~d}$ & Well-established granulation tissue with neovascularization and collagen deposition \\
$2-8 \mathrm{wk}$ & Progressively decreasing cellularity with increasing fibrosis \\
$>2 \mathrm{mo}$ & Dense fibrotic scar \\
\hline
\end{tabular}

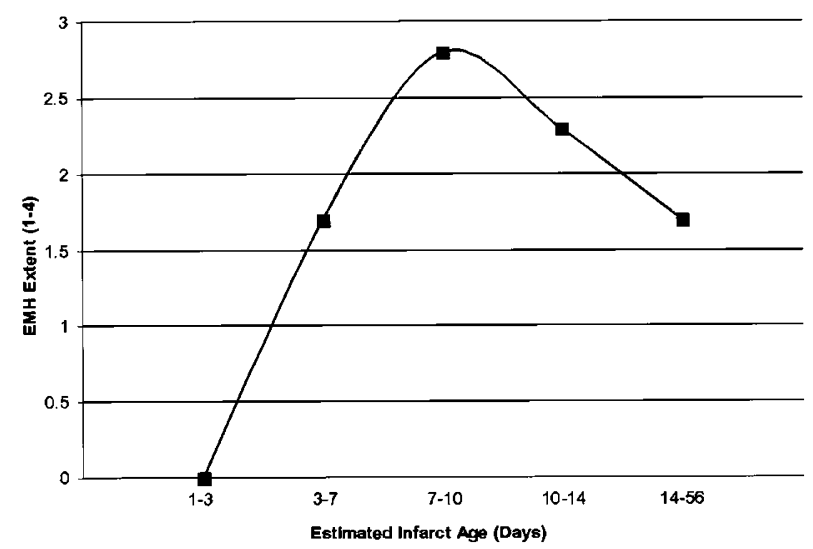

FIGURE 8. Extent of extramedullary hematopoiesis with infarct age. Peak extent of extramedullary hematopoiesis was seen in 7- to 10-dayold infarcts corresponding to the morphologic findings of abundant macrophages and granulation tissue development.

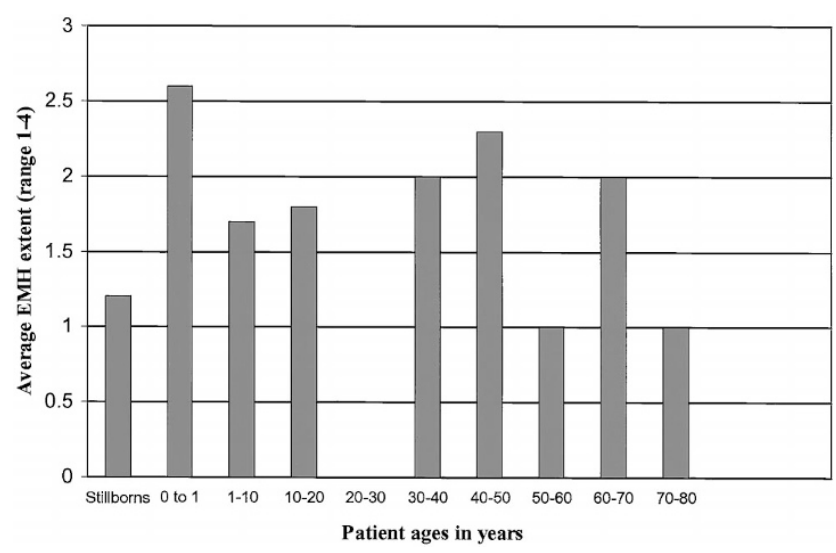

FIGURE 9. Extent of extramedullary hematopoiesis with patient age. There was no correlation between patient age and extent of extramedullary hematopoiesis.

EMH occurs at such a high frequency but that it has not been recognized at this frequency before.

\section{REFERENCES}

1. Oyer CE, Singer DB. The hematopoietic system. In: Wigglesworth JS, Singer DB, editors. Textbook of fetal and perinatal pathology. 2nd ed. Malden, MA: Blackwell Science; 1998. p. 1143.

2. Kelemen E, Calvo W, Fleidner TM. Atlas of human hemopoietic development. New York: Springer; 1979. p. 3-81.

3. Favara BE. The bone marrow and histiocytosis syndromes. In: Stocker JT, Dehner LP, editors. Pediatric pathology. Phil- adelphia: JB Lippincott; 1992. p. 1033.

4. Dimmick JE, Jevon GP. Liver disease in the perinatal infant. In: Wigglesworth JS, Singer DB, editors. Textbook of fetal and perinatal pathology. 2nd ed. Malden, MA: Blackwell Science; 1998. p. 866.

5. Aster J, Kumar V. White cells, lymph nodes, spleen, and thymus. In: Cotran RS, Kumar V, Collins T, editors. Robbins pathologic basis of disease. 6th ed. Philadelphia: WB Saunders; 1999. p. 682-3.

6. Cotran RS, Kumar V, Collins T. Red cells and bleeding disorders. In: Cotran RS, Kumar V, Collins T, editors. Robbins pathologic basis of disease. 6th ed. Philadelphia: WB Saunders; 1999. p. 615-9.

7. Zec N, Cera P, Twofighi J. Extramedullary hematopoiesis in cerebellar hemangioblastoma. Neurosurgery 1991;29:34-7.

8. Green LK, Klima M, Burns TR. Extramedullary hematopoiesis occurring in a hemangioma of the skin. Arch Dermatol 1998;124:1720-1.

9. Ishak KG, Glunz PR. Hepatoblastoma and hepatocarcinoma in infancy and childhood: report of 47 cases. Cancer 1967; 20:396-422.

10. Schmid C, Beham A, Kratochvil P. Hematopoiesis in a degenerating uterine leiomyoma. Arch Gynecol Obstet 1990; 248:81-6.

11. Kaddu S, Beham-Schmid C, Soyer HP, Hodl S, Beham A, Kerl H. Extramedullary hematopoiesis in pilomatricomas. Am J Dermatopathol 1995;17(2):126-30.

12. Kojiro M, Nakashima T, Ito Y, Ikezaki H, Mori T, Kido C. Thorium dioxide-related angiosarcoma of the liver: pathomorphologic study of 29 autopsy cases. Arch Pathol Lab Med 1985;1099:853-7.

13. Sirgi KE, Swanson PE, Gersell DJ. Extramedullary hematopoiesis in the endometrium: report of four cases and review of the literature. Am J Clin Pathol 1994;101:643-6.

14. Gregorios JB, Bay JW, Dudley AW Jr. Extramedullary hematopoiesis in a malignant meningioma. Neurosurgery 1983; 13:447-51.

15. Wheeler DA, Edmondson HA, Reynolds TB. Spontaneous liver cell adenoma in children. Am J Clin Pathol 1986;85:612.

16. Sibley RK, Dehner LP. Kidney. In: Dehner LP, editor. Pediatric surgical pathology. 2nd ed. Baltimore: Williams \& Wilkins; 1987. p. 652.

17. Lewis DJ, Moul AJW, Williams SC, Sesterhenn IA, Colon E. Perirenal liposarcoma containing extramedullary hematopoiesis associated with renal cell carcinoma. Urology 1994; 43:106-9.

18. Tsamandas AC, Jain AB, Raikow RB, Demetris AJ, Nalesnik MA, Randhawa PS. Extramedullary hematopoiesis in the allograft liver. Mod Pathol 1995;8(6):671-4.

19. Schlitt HJ, Schafers S, Deiwick A, Eckardt KU, Pietsch T, Ebell W, et al. Extramedullary erythropoiesis in human liver grafts. Hepatology 1995;21:689-96.

20. Bacchi CE, Rocha N, Carvalho M, Schmitt D, Schmitt F, Franco M. Immunohistochemical characterization of probable intravascular haematopoiesis in the vasa rectae of the renal medulla in acute tubular necrosis. Pathol Res Pract 
1994;190:1066-70.

21. Humphrey PA, Wick MR. Pseudoneoplastic pathologic conditions of the breast and endocrine system. In: Wick MR, Humphrey PA, Ritter JH, editors. Pathology of pseudoneoplastic lesions. Philadelphia: Lippincott-Raven; 1997. p. 332.

22. Groark SP, Jampel RM. Violaceous papules and macules in a newborn: dermal erythropoiesis associated with congenital viral infection. Arch Dermatol 1989;125:116-7.

23. Marley EF, Liapis J, Hess JL, Dehner LP. Myocardial extramedullary hematopoiesis following myocardial infarction. Cardiovasc Pathol 1996;5:333-6.

24. Hsu S-M, Raine L, Fanger H. Use of avidin-biotin-peroxidase complex $(\mathrm{ABC})$ in immunoperoxidase techniques: a comparison between $\mathrm{ABC}$ and unlabeled antibody (PAP) procedures. J Histochem Cytochem 1981;29:577-80.

25. Heller EL, Leisohn MG, Palin WE. Aleukemic myelosis, chronic non-leukemic myelosis, agnogenic myeloid metaplasia, osteosclerosis, leukoerythroblastic anemia, and synonymous designations. Am J Pathol 1947;23:327-65.
26. Wyatt JP, Sommers SC. Chronic marrow failure, myelosclerosis and extramedullary hematopoiesis. Blood 1950;5:32947.

27. Dameshek W. Some speculations on the myeloproliferative syndromes. Blood 1951;6:372-5.

28. Wolf BC, Neiman RS. Hypothesis: splenic filtration and the pathogenesis of extramedullary hematopoiesis in agnogenic myeloid metaplasia. Hematol Pathol 1987;1(1):77-80.

29. O'Keane JC, Wolf BC, Neiman RS. The pathogenesis of splenic extramedullary hematopoiesis in metastatic carcinoma. Cancer 1989;63:1539-43.

30. Schwarzmeier JD. The role of cytokines in haematopoiesis. Eur J Haematol 1996;57(Suppl):69-74.

31. Nimer SD, Uchida H. Regulation of granulocyte-macrophage colony-stimulating factor and interleukin 3 expression. Stem Cells 1995;13:324-35.

32. Schoen FJ. The heart. In: Cotran RS, Kumar V, Collins T, editors. Robbins pathologic basis of disease. 6th ed. Philadelphia: WB Saunders; 1999. p. 557-9.

\section{Book Review}

\section{Rubin E, Farber J: Pathology Image Collection [CD-ROM], Lippincott Williams \& Wilkins, 2000 (\$795).}

This superb set of images from Rubin and Farber's Pathology, 3rd Edition (1999), published by Lippincott Williams \& Wilkins, consists of 10 CDs with all of the photographs and illustrations in this fine textbook. Adobe PhotoShop 5.0 was used with a PC running at $133 \mathrm{MHz}$ with $32 \mathrm{MB}$ of RAM to view the material. Image sizes varied from approximately 0.275 to $8 \mathrm{MB}$, and access times varied from 2 to 40 seconds, respectively. The majority of the images fell within a range of 2 to 4 MB. Advice from the publisher's Technical Support section suggested $500 \mathrm{MHz}$ of speed and a minimum of $64 \mathrm{MB}$ of RAM.

Image quality in general paralleled those in the text. A call to the publisher indicated that permission to copy images for use in another software program such as PowerPoint was necessary from the illustrator or author of the photographs. Accordingly, if used in a formal class, access times would be a burden. This problem could have been obviated by a duplicate set of images of more manageable size. Nonetheless, the CD image collection would work well for smaller groups of students at the computer. This excellent set of images should be placed in every medical school library computer section for use by the students.

\author{
James R. Newland \\ University of Nebraska Medical Center \\ Omaha, Nebraska
}

